\title{
EFFECT OF EARLY MOBILIZATION AND JACOBSON'S RELAXATION ON THE RECOVERY OF PSYCHOMOTOR FUNCTION AMONG POST CAESARIAN SECTION WOMEN
}

\author{
Vivin Sari Sukmawati, Wahyuni \\ Study Program in Physiotherapy, Faculty of Health Sciences, \\ Universitas Muhammadiyah Surakarta
}

\begin{abstract}
Background: The adoption of enhanced recovery after surgery in the obstetric patient population is rapidly gaining popularity. Enhanced recovery after surgery aims to produce rapid positive patient outcomes. Jacobson's relaxation technique is a type of therapy that focuses on tightening and relaxing specific muscle groups in sequence. By concentrating on specific areas and tensing and then relaxing them, one can become more aware of the body and physical sensations. This study aimed to determine the effect of early mobilization after caesarian section combined with Jacobson's relaxation on psychomotoric functional recorvery.

Subjects and method: This was a quasi experiment before and after with no control design. This study was conducted at Simo Hospital, Boyolali, Central Java. A sample of 24 post caesarian section women was selected for this study. The dependent variable was psychomotoric functional recorvery. The independent variable was early mobilization with Jacobson's relaxation technique. The data were collected from medical record and questionnaire. The data were analyzed by Wilcoxon test.

Results: The psychomotoric function after early mobilization and Jacobson's relaxitation technique was about equal as it was before caesarian section ( $\mathrm{p}=$ 0.205).

Conclusion: Early mobilization combined with Jacobson's relaxitation technique is effective to help women to recover psychomotoric function after caesarian section.
\end{abstract}

Keywords: psychomotoric function, post section caesaria, early mobilization, Jacobson's relaxation technique

\section{Correspondence:}

Vivin Sari Sukmawati. Study Program in Physiotherapy, Faculty of Health Sciences, Universitas Muhammadiyah Surakarta, Surakarta, Central Java.

Email: vivinsarisukmawati@gmail.com. Mobile: 085330462404.

The 4th International Conference on Public Health

Best Western Premier Hotel, Solo, Indonesia, August 29-30, $2018 \mid 178$

https://doi.org/10.26911/theicph.2018.03.09 